\title{
Anatomical and Histochemical Characterization of Leaves of Luffa cylindrica (L.) M. Roem
}

\author{
Laís Emanuelle Bernardo Vieira, Rafaela Damasceno Sá, Karina Perrelli Randau*
}

Laís Emanuelle Bernardo Vieira, Rafaela Damasceno Sá, Karina Perrelli Randau*

\section{Departamento de Ciências}

Farmacêuticas, Universidade Federal de Pernambuco, Avenida Professor Arthur de Sá, Cidade Universitária, Recife, $P E$, BRAZIL.

\section{Correspondence}

Dr. Karina Perrelli Randau

Departamento de Ciências Farmacêuticas, Laboratório de Farmacognosia, Universidade Federal de Pernambuco, Av. Prof. Arthur de Sá S/N CDU, Recife-PE CEP: 50740-521, BRAZIL.

Phone no : +55-81-988225279

E-mail: krandau@hotmail.com

\section{History}

- Submission Date: 19-11-2018;

- Review completed: 28-01-2019;

- Accepted Date: 12-02-2019

DOI : 10.5530/pj.2019.11.81

Article Available online http://www.phcogj.com/v11/i3

\section{Copyright}

(c) 2019 Pharmacognosy Journal. This is an open-access article distributed under the terms of the Creative Commons Attribution 4.0 International license.

\begin{abstract}
Background: Luffa cylindrica (L.) M. Roem. (Cucurbitaceae) is an herbaceous plant used for food as compose salads and do sweets and also used in traditional medicine as treat parasitic infections and intestinal diseases. Although this information, there are not many relates about anatomic characters for use in your quality control. Objective: The aim was investigating the anatomical characters of petiole and leaf blade and characterizing the metabolites in the leaf blade of L. cylindrica. Materials and Methods: Semipermanent histological slides were prepared for analysis of petiole and leaf blade in optical microscopy. Histochemical tests were also performed in the leaf blade. Results: The anatomical study revealed information about the type of trichomes, cuticle, vascular bundles and arrangement of the tissues that determine the botanical identity of this species. It was also identifying, for the first time, the presence of two types of trichomes in both of leaf blades faces. The histochemistry allowed determining which metabolites are in the leaf blade and also their location. Conclusion: The study described new characters for L. cylindrica and the results provide support to quality control of the species.

Key words: Anatomy, Cucurbitaceae, Histochemistry, Luffa cylindrica, Microscopy.
\end{abstract}

\section{INTRODUCTION}

The Cucurbitaceae family have 134 genera and encompass over 965 species. The principal genera about to the family are Bryonopsis, Citrullus, Corallocarpus, Cucumis, Cucurbita, Lagenaria, Luffa, Momordica and Trichosanthes and they can be cultivated in the tropics, subtropics, arid and temperate regions. ${ }^{1-3}$

The cucurbits are herbaceous. The most species having large leaves, the foliage is whole or in deep lobes and they can be climbing or creeping plants. The flowers are having differences sexes and a large inferior ovary. After fertilization, the ovary develops into a fruit processing hard exocarp, fleshy mesocarp and endocarp..$^{4-5}$ Many cucurbits' fruits have been an ingredient for the culinary and are eaten when immature or mature by salads, sweets, desserts or pickled. ${ }^{6-7}$

Besides being food, some species are often used in popular medicine throughout the world, such as in America, ${ }^{8-9}$ Africa $^{10-11}$ and Asia. ${ }^{12-13}$ The principal parts of the plant used to treat icterus, gastric diseases, diabetes, sinusitis, lung diseases, fever, cancer, inflammation, skin infections, pain, among others, are roots, leaves, fruits and seeds. ${ }^{8-13}$ Many plants of the Cucurbitaceae family contain cucurbitanes, which is a type of triterpene. ${ }^{14}$

Brazil has some cucurbit genera. Around 28 genera and 160 species occur in all states in the country. Among them, Luffa is a genus it has had two species: Luffa cylindrica (L.) M. Roem. moreover, Luffa operculata
(L.) Cogn. ${ }^{15}$ Luffa cylindrica is popularly known as "Bucha" and its root, leaves, fruits and seeds has been used to treat infections and gastric disease. ${ }^{16-17}$ The leaves are used in Guinea Bissau to intestinal diseases, fever and malaria, ${ }^{18}$ in Bolivia to anuria, ${ }^{19}$ in Cuba to parasitic infections, ${ }^{20}$ in India to indigestion ${ }^{21}$ and in Pakistan as laxative. ${ }^{22}$

Although the medicinal use of Cucurbitaceae family has been much reported in the literature, the quality control about many members of its family is not too reported. Therefore, this research aimed to perform the anatomic and histochemistry characterization of leaves of L. cylindrica, in order to expend the pharmacobotanical information about species of Cucurbitaceae family.

\section{MATERIALS AND METHODS}

\section{Plant material}

Adult leaves of specimens of Luffa cylindrica (L.) M. Roem., Cucurbitaceae, were collected in the city of Aliança, Pernambuco, Brazil. A voucher specimen was deposited in the Herbarium Dárdano de Andrade Lima of the Instituto Agronômico de Pernambuco (IPA), under collection number 92082.

\section{Anatomical characterization}

Cross-sections were obtained by hand, using a common razor blade, at the middle region of petiole
Cite this article: Vieira LEB, Sá RD, Randau KP. Anatomical and Histochemical Characterization of Leaves of Luffa cylindrica (L.) M. Roem. Pharmacog J. 2019;11(3):511-4. 
and leaf blade fixed in FAA $50 .{ }^{23}$ Leaf blade paradermal sections were also performed on the adaxial and abaxial surfaces. All sections were clarified with sodium hypochlorite solution (50\%), ${ }^{24}$ followed by washing with distilled water. Lastly, cross-sections were stained with safranin and astra blue ${ }^{25}$ and paradermal sections were stained with methylene blue (1\%). ${ }^{26}$ Semipermanent histological slides were prepared to contain the sections of botanical material, following common plant anatomy procedures. ${ }^{23,27}$ The analysis of the slides was conducted using a polarized microscope (Leica DM750M) coupled with a digital camera (Leica ICC50 W), through images processed in software (LAS EZ).

\section{Histochemical characterization}

Histochemical tests were made on cross-sections of fresh leaf blades obtained by hand, using a common razor blade..$^{23}$ The specific reagents used were: potassium dichromate $(10 \%)$ for phenolic compounds, ${ }^{28}$ Dragendorff's reagent for detecting alkaloids, ${ }^{29}$ vanillin-chloridric acid for tannins, ${ }^{30}$ antimony trichloride for triterpenes and steroids, ${ }^{31} \mathrm{Nadi}$ reagent for essential oils, ${ }^{32}$ Sudan III for lipophilic substances, ${ }^{27}$ phloroglucinol for lignin, ${ }^{23}$ Lugol's iodine reagent for starch..$^{23}$ Controls were performed in parallel with the tests and semipermanent histological slides were prepared containing the cross-sections, ${ }^{23,27}$ which were analyzed under an optical microscope (Alltion).

\section{RESULTS}

In cross-section, the petiole of $L$. cylindrica has rounded outline, with two ribs in the adaxial face (Figure 1A, B). It shows an epidermis with a single stratum of cells, covered with a thin cuticle (Figure 1A). This species present two types of trichomes: the non-glandular trichomes and the glandular trichomes. The non-glandular trichomes are pluricellular uniseriate and the glandular trichomes have peduncle and apex both of them multicellular (Figure 1C, D). The collenchyma has an angular form and its constitution is around four to five cell layers (Figure 1A). The vascular system is composed of eleven bicollateral vascular bundles, being two bundles in two ribs on the adaxial face (Figure 1A) and nine bundles are in the central region of the petiole, forming a ring (Figure 1B).

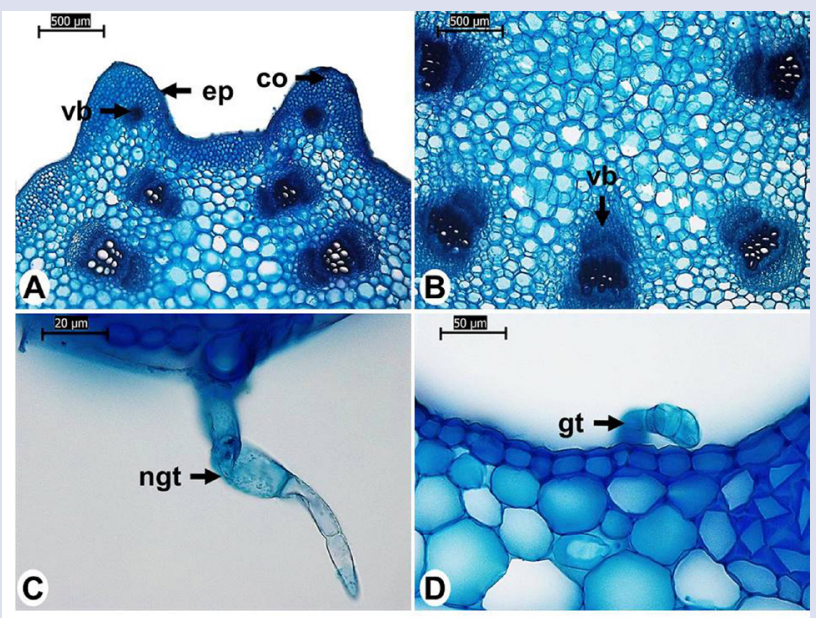

Figure 1: Cross-Sections of the Petiole of Luffa cylindrica (L.) M. Roem. A, B. General view. C. Non-glandular trichome. D. Glandular trichome. co: Collenchyma, ep: Epidermis, gt: Glandular trichome, ngt: Non-glandular trichome, vb: Vascular bundle.

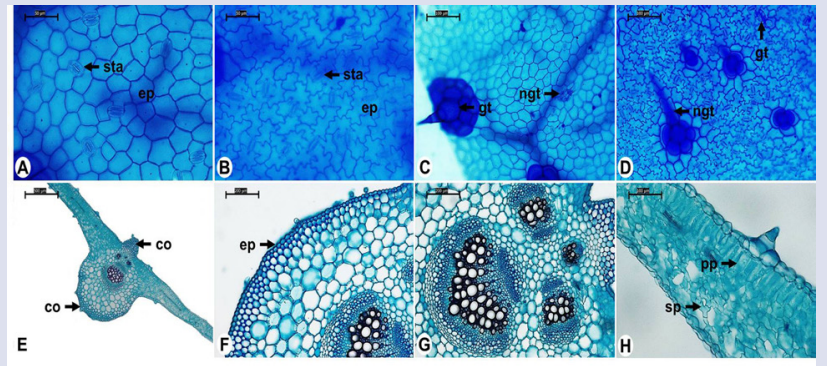

Figure 2: Frontal view and cross-sections of the leaf blade of Luffa cylindrica (L.) M. Roem. A, C. Adaxial surface. B, D. Abaxial surface. E, F, G. Midrib. H. Mesophyll. co: Collenchyma, ep: Epidermis, gt: Glandular trichome, ngt: Non-glandular trichome, pp: Palisade parenchyma, sp: Spongy parenchyma, sta: Stomata.

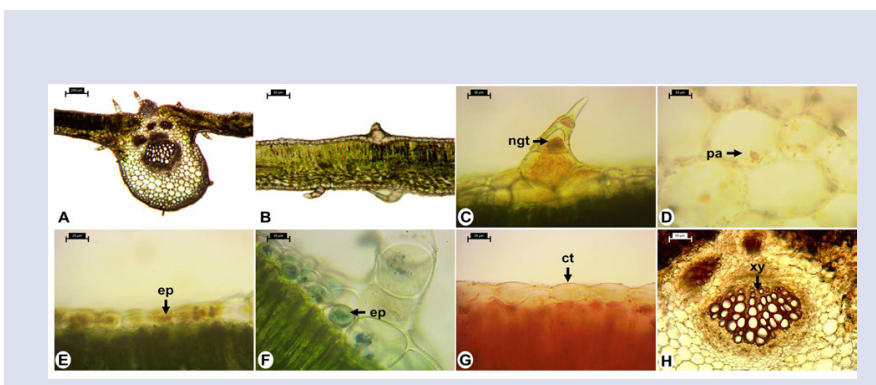

Figure 3: Histochemistry of the leaf blade of Luffa cylindrica (L.) M. Roem. A, B. Control. C. Potassium dichromate (10\%). D. Dragendorff's reagent. E. Antimony trichloride. F. Nadi reagent. G. Sudan III. H. Phloroglucinol. ct: Cuticle, ep: Epidermis, ngt: Non-glandular trichome, pa: Parenchyma, xy: Xylem.

The leaf blade, in frontal view, is amphistomatic with anomocytic stomata (Figure 2A, B). The epidermis has cell walls with the straight or slightly sinuous contour on the adaxial face (Figure 2A), although in the abaxial face the epidermis has cell walls with a strongly sinuous contour (Figure 2B). Both of them leaf blade faces have the same types of trichomes seen at petiole (Figure 2C, D).

In cross-section, the midrib has a biconvex outline (Figure 2E). Its epidermis is uniseriate with thin cuticle (Figure $2 \mathrm{~F}$ ). The collenchyma is angular composed of eight to ten cells layer in the adaxial face and two to three cells layer in the abaxial face (Figure $2 \mathrm{E}$ ). The vascular system is made with bundles arranged in ring form as the petiole, however in midrib are just four bundles (Figure $2 \mathrm{G}$ ). About the bundle distribution, three of them are bicollateral and one comes back to adaxial face and it is collateral. The mesophyll is dorsiventral with one layer of palisade parenchyma and its spongy parenchyma has braciform cells (Figure $2 \mathrm{H}$ ). The Figure 3A and 3B show the cross-section of leaf blade without the addition of reagent. After the addition of reagents to identify secondary metabolites were obtained these results: phenolic compounds were found in non-glandular trichomes (Figure 3C); alkaloids were seen in parenchyma of the midrib (Figure 3D); triterpenes, steroids and essentials oils were evidenced in epidermal cells (Figure 3E, F); Sudan III revealed lipophilic compounds in cuticle (Figure $3 \mathrm{G}$ ) and the phloro- 
glucinol showed the existence of lignin in xylem (Figure 3H). Negative results were identified for tannins and starch.

\section{DISCUSSION/ CONCLUSION}

The petiole outline found in L. cylindrica is different from other species of Cucurbitaceae family. Rus et al..$^{33}$ found a semicircular outline, laterally compressed in Bryonia alba L. In Momordica charantia L., Sá et al. ${ }^{34}$ observed a convex outline with two ribs on the adaxial surface and a triangular outline on the abaxial surface. M. tuberosa Cogn. revealed a convex outline on the adaxial surface and triangular outline on the abaxial surface..$^{35}$ About the presence of collenchyma in the petiole, this tissue has also been observed in B. alba and some species of Momordica. ${ }^{36}$ In the latter case, Aguoru and Okoli have verified that the number of collenchyma layers can be a character to differentiate them. ${ }^{36}$ In the same work with species of Momordica, Aguoru and Okoli described that the number of bicollateral vascular bundles in the petiole ranged from six to eighteen. ${ }^{36}$ Sãvulescu and Hoza ${ }^{37}$ found seven bicollateral bundles in the central region of the petiole and two bicollateral bundles in the ribs of M. charantia, while Sá et al. ${ }^{34}$ visualized five bicollateral bundles in the central region of the petiole and two bicollateral bundles in the ribs of $M$. charantia. Rus et al. ${ }^{33}$ found nine bicollateral bundles in B. alba, being two situated near the compression.

The number of vascular bundles also varies in the leaf blade of the Cucurbitaceae species. Ajuru and Okoli ${ }^{38}$ identified eight bicollateral bundles in Cucumis melo L., four in Cucurbita moschata Duchesne and two in Cucumeropsis mannii Naudin. Mohammed and Guma ${ }^{39}$ reported the presence of seven bicollateral bundles in species of Citrullus and Cucurbita, three in Cucumis and four in Luffa. Although the presence of bicollateral bundles in the family is common, ${ }^{40}$ in this research was identified one collateral vascular bundle in the leaf blade of L. cylindrica. Collateral vascular bundles have also been identified in $B$. alba $a^{33}$ and M. charantia..$^{41}$

Non-glandular and glandular trichomes are common in the family Cucurbitaceae and, in this study, they were found in the petiole and leaf blade of L. cylindrica. Some researches relative to leaf blade of Luffa species mentioned only the presence of non-glandular trichomes as in L. acutangular (L.) Roxb., L. echinate Roxb., L. cylindrica ${ }^{38}$ and L. aegyptiaca. ${ }^{39}$ Alves et al. ${ }^{42}$ described non-glandular and glandular trichomes in L. aegyptiaca and Rus et al..$^{33}$ in B. alba. Thus, in this work is possible to note the first description about the presence of non-glandular and glandular trichomes in L. cylindrica.

Alves et $a l .{ }^{42}$ showed that L. aegyptiaca also has an amphistomatic leaf blade, with anomocytic stomata. However, a useful character to distinguish it from L. cylindrica is that L. aegyptiaca presents collenchyma only on the adaxial face of the midrib, while L. cylindrica showed collenchyma in both faces. ${ }^{39}$ In relation to mesophyll, in C. melo, C. moschata and C. mannii the palisade parenchyma is constituted of two to three layers of cells. ${ }^{38}$ Phytochemical investigations demonstrated the presence of phenolic compounds, alkaloids, terpenes and steroids in leaves of L. cylindrica, ${ }^{43-45}$ corroborating the results found through histochemistry tests in this study. The presence of tannins in the leaves of the species is divergent, as it was not evidenced in the present study nor the investigation of Aboh et al. ${ }^{44}$ but Partap et al. ${ }^{43}$ evidenced tannins. Flavonoids, tannins, alkaloids and terpenes have been identified in L. acutalanga and L. aegyptiaca. ${ }^{46-48}$

The findings of this study can be used as a tool for identification of L. cylindrica and assists in its pharmacobotanical standardization.

\section{ACKNOWLEDGEMENT}

The authors are grateful to Coordenação de Aperfeiçoamento de Pessoal de Nível Superior (CAPES).

\section{CONFLICT OF INTEREST}

There are no conflicts of interest.

\section{ABBREVIATIONS}

CO: Collenchyma; CT: Cuticle; EP: Epidermis; GT: Glandular Trichome; NGT: Non-Glandular Trichome; PA: Parenchyma; PP: Palisade Parenchyma; SP: Spongy Parenchyma; STO: Stomata; VB: Vascular Bundle; XY: Xylem..

\section{REFERENCES}

1. Dhiman K, Gupta A, Sharma DK, Gill NS, Goyal A. A review on the medicinally important plants of the family Cucurbitaceae. Asia J Clin Nutr. 2012;4(1):16-26.

2. The Plant List. Version 1.1. Published on the Internet. 2013

3. Paris HS, Tadmor Y, Schaffer AA. Cucurbitaceae Melons, Squash, Cucumber Encyclopedia of Applied Plant Sciences. 2017;3:209-17.

4. Joly AB. Botânica: introdução à taxonomia vegetal. São Paulo: Companhia Editora Nacional. 1993.

5. Souza VC, Flores TB, Lorenzi H. Introdução à botânica: morfologia. São Paulo: ILista de Espécies da Flora do Brasil. 2013.

6. Lorenzi H, Lacerda MTC, Bacher LB. Frutas no Brasil: nativas e exóticas (de consumo in natura). São Paulo: Instituto Plantarum de Estudos da Flora. 2015.

7. Lorenzi H. Plantas daninhas do Brasil: terrestres, aquáticas, parasitas e tóxicas. Nova Odessa: Instituto Plantarum. 2008.

8. Coe FG. Rama midwifery in eastern Nicaragua. J Ethnopharmacol. 2008;117(1):136-57.

9. Ribeiro RV, Bieski IGC, Balogun SO, Martins DTO. Ethnobotanical study of medicinal plants used by Ribeirinhos in the North Araguaia microregion, Mato Grosso, Brazil. J Ethnopharmacol. 2017;205:69-102.

10. Amujoyegbe OO, Idu M, Agbedahunsi JM, Erhabor JO. Ethnomedicinal survey of medicinal plants used in the management of sickle cell disorder in Southern Nigeria. J Ethnopharmacol. 2016;185:347-60.

11. Kidane B, Andel T, Maesen LJG, Asfaw Z. Use and management of traditional medicinal plants by Maale and Ari ethnic communities in southern Ethiopia. $J$ Ethnobiol Ethnomed. 2014;10(1):46.

12. Sharma J, Gairola S, Gaur RD, Painuli RM. The treatment of jaundice with medicinal plants in indigenous communities of the Sub-Himalayan region of Uttarakhand, India. J Ethnopharmacol. 2012;143(1):262-91.

13. Hong L, Guo Z, Huang K, Wei S, Liu B, Meng S, et al. Ethnobotanical study on medicinal plants used by Maonan people in China. J Ethnobiol Ethnomed. 2015; $11(1): 32$

14. Azeez MA, Bello OS, Adedeji AO. Traditional and medicinal uses of Luffa cylindrica: a Review. J Med Plants Stud. 2013;1(5):102-11.

15. Gomes-Klein VL, Lima LFP, Gomes-Costa GA, Medeiros ES, Jardim Botânico do Rio de Janeiro. Cucurbitaceae in Lista de Espécies da Flora do Brasil. Jardim Botânico DoRio DeJaneiro. 2015.

16. Coelho-Ferreira M. Medicinal knowledge and plant utilization in an Amazonian coastal community of Marudá, Pará State (Brazil). J Ethnopharmacol. 2009;126(1):159-75.

17. Bolson M, Hefler SR, Dall El, Chaves O, Junior AG, Junior ELC. Ethno-medicinal study of plants used for treatment of human ailments, with residents of the surrounding region of forest fragments of Paraná, Brazil. J Ethnopharmacol. 2015;161:1-10.

18. Catarino L, Havik PJ, Romeiras MM. Medicinal plants of Guinea-Bissau: Therapeutic applications, ethnic diversity and knowledge transfer. J Ethnopharmacol. 2016;183:71-94.

19. Bourdy G, Michel LC, Roca-Coulthard A. Pharmacopoeia in a shamanistic society: the Izoceno-Guaranı (Bolivian Chaco). J Ethnopharmacol. 2004;91(2-3):189-208.

20. Cano $\mathrm{JH}$, Volpato G. Herbal mixtures in the traditional medicine of Eastern Cuba. J Ethnopharmacol. 2004;90(2-3):293-316.

21. Chander MP, Kartick C, Vijayachar P. Ethnomedicinal knowledge among Karens of Andaman and Nicobar Islands, India. J Ethnopharmacol. 2015;162:127-33.

22. Ishtiaq M, Mahmood A, Maqbool M. Indigenous knowledge of medicinal plants from Sudhanoti district (AJK), Pakistan. J Ethnopharmacol. 2015;168:201-7.

23. Johansen DA. Plant microtechnique. New York: McGraw-Hill. 1940

24. Kraus JE, Arduin M. Manual básico de métodos em morfologia vegetal. Rio DeJaneiro: EDUR. 1997

25. Bukatsch F. Bemerkungen zur doppelfärbung Astrablau-Safranin. Mikrokosmos 1972;61(8):255

26. Krauter D. Erfahrungen mit Etzolds FSA-Färbung für pflanzenschnitte. Mikrokosmos. 1985;74:231-3.

27. Sass JE. Botanical microtechnique. Ames: Iowa State College Press. 1951

28. Gabe M. Techniques histologiques. Paris: Masson and Cie. 1968.

29. Yoder LR, Mahlberg PG. Reactions of alkaloid and histochemical indicators in 
laticifers and specialized parenchyma cells of Catharanthus roseus (Apocynaceae). Am J Bot. 1976;63(9):1167-73.

30. Mace MZ, Howell CR. Histochemistry and identification of condensed tannin precursors in roots of cotton seedlings. Can J Bot. 1974;52(11):2423-6.

31. Mace ME, Bell AA, Stipanovic RD. Histochemistry and isolation of gossypol and related terpenoids in root of cotton seedlings. Phytopathology. 1974;64:1297-302.

32. David R, Carde JP. Coloration différentielle des inclusions lipidiques et terpéniques des pseudophylles du Pin maritime au moyen du réactif nadi. C R Acad Sci Paris Ser D. 1964;258(4):1338-40.

33. Rus L, lelciu II, Paltinean R, Vlase L, Stefanescu C, Crisan G. Morphological and histo-anatomical study of Bryonia alba L. (Cucurbitaceae). Not Bot Horti Agrobot Cluj Napoca. 2015;43(1):47-52

34. Sá RD, Cadena MB, Padilha RJR, Alves LC, Randau KP. Anatomical study and characterization of metabolites in leaves of Momordica charantia L. Pharmacogn J. 2018;66:1-4.

35. Kumar P, Rao D, Bilakanti L, Setty R. Pharmacognostical studies on Momordica tuberosa Cogn. Pharmacogn J. 2010;2(5):28-33.

36. Aguoru CU, Okoli BE. Comparative stem and petiole anatomy of West African species of Momordica L (Cucurbitaceae). Afr J Plant Sci. 2012;6(15):403-9.

37. Sãvulescu E, Hoza G. Research results regarding the anatomy of Momordica charanthia L. specie. Lucrari stiintifice USAMVB, Seria B, LIV. 2010;2010(54):694-700.

38. Ajuru MG, Okoli BE. Comparative vegetative anatomy of some species of the Family Cucurbitaceae Juss in Nigeria. Res J Bot. 2013;8(1):15-23.

39. Mohammed IA, Guma AGN. Anatomical diversity among certain genera of family Cucurbitaceae. Int J Res Stud Biosci. 2015;3:85-91.

40. Metcalfe CR, Chalk L. Anatomy of the dicotyledons: leaves, stem and wood in relation to taxonomy with notes on economic uses. Oxford: Clarendon Press.
1950

41. Coutinho DF, Florêncio JC, Aguiar LR, Rodrigues KAF Vilanova CM, Borba ERC. Estudo farmacobotânico das folhas de Momordica charantia L. (Cucurbitaceae). Visão Acadêmica. 2009;10:7-17.

42. Alves RM, Inacio EM, Monquero PA, Meneghin SP, Hirata ACS. Leaf-surface characterization and the effects of the herbicide saflufenacil on the leaves of weeds. Rev Bras Ciênc Agr. 2014;9(4):550-5.

43. Partap S, Kumar S, Kumar A, Sharma NK, Jha KK. In-vitro anthelmintic activity of Luffa cylindrica leaves in Indian adult earthworm. J Pharmacogn Phytochem. 2012;1(2):27-30

44. Aboh MI, Oladosu P, Adeshina G, Olayinka B, Olonitola SO. Phytochemical screening and antifungal activity of leaves extracts of Luffa cylindrica (Roem). Afr J Microbiol Res. 2017;11(47):1681-7.

45. Abdel-Salam IM, Ashmawy AM, Hilal AM, Eldahshan OA, Ashour M. Chemica composition of aqueous-ethanol extract of Luffa cylindrica leaves and its effect on representation of caspase 8, caspase 3 and the proliferation marke Ki67 in intrinsic molecular sub-types of breast cancer in vitro. Chem Biodivers. 2018; 15:e1800045.

46. Suradkar VB, Wankhade BB, Patil SH, Narkhede NN, Bhokare ID Quantitative determination of some phytochemical contents of various plant seeds and leaves of water, ethanol and methanol extracts. Int J Inf Res Rev. 2017;4261-4

47. Mankilik M, Mikailu A, Mhya DH. Phytochemical content and antimicrobial activities of Luffa aegyptiaca (Sponge gourd) leaves extracts. Int J Res Pharm Biosci. 2014:1:1-4.

48. Mhya DH, Mankilik M. Phytochemical screening of aqueous extract of Luffa aegyptiaca (sponge gourd) leave sample from Northern Nigeria: A short communication. Int J Pharm Sci Res. 2014:5:344-5.

\section{GRAPHICAL ABSTRACT}

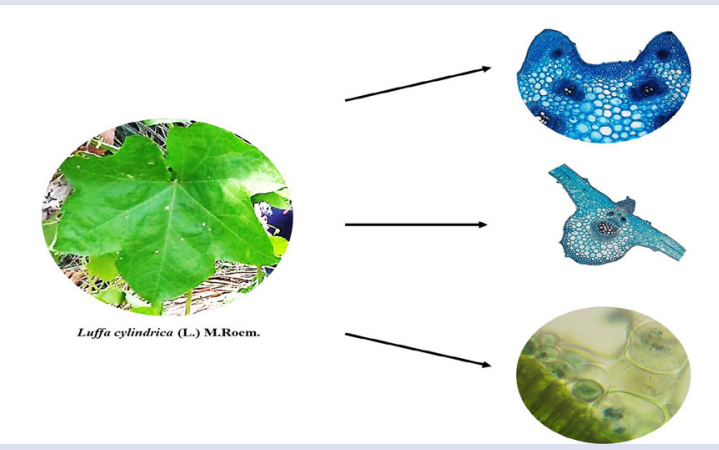

\section{SUMMARY}

- Luffa cylindrica (L.) M. Roem. (Cucurbitaceae) is an herbaceous plant used for food as compose salads and do sweets and also used in traditional medicine as treat parasitic infections and intestinal diseases. Although this information, there are not many relates about anatomic characters for use in your quality control. The aim was investigating the anatomical characters of petiole and leaf blade and characterizing the metabolites in the leaf blade of $L$. cylindrica. Semipermanent histological slides were prepared for analysis of petiole and leaf blade in optical microscopy. Histochemical tests were also performed in the leaf blade. The anatomical study revealed information about the type of trichomes, cuticle, vascular bundles and arrangement of the tissues that determine the botanical identity of this species. It was also identifying, for the first time, the presence of two types of trichomes in both of leaf blades faces. The histochemistry allowed determining which metabolites are in the leaf blade and also their location. The study described new characters for L. cylindrica, and the results provide support to quality control of the species.

\section{ABOUT AUTHORS}

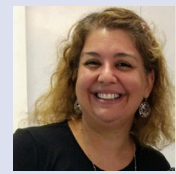

Karina Perrelli Randau is an Associate Professor at the Pharmacy Course, Universidade Federal de Pernambuco (UFPE). She is professor of the Postgraduate Program in Therapeutic Innovation (UFPE). She has projects in collaboration with national institutions. Has experience in the area of Pharmacy, with emphasis on Pharmacobotany, Pharmacognosy and Phytochemistry.

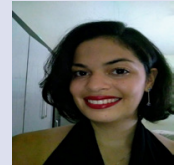

Laís Emanuelle Bernardo Vieira is a Pharmacist, graduated by Universidade Federal de Pernambuco. She is MSc in Therapeutic Innovation.

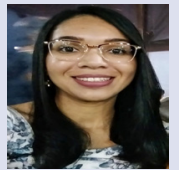

Rafaela Damasceno Sá is a Pharmacist, graduated by Universidade Federal de Pernambuco. She is PhD in Therapeutic Innovation and develops work in the area of Pharmacobotany and Pharmacognosy.

Cite this article: Vieira LEB, Sá RD, Randau KP. Anatomical and Histochemical Characterization of Leaves of Luffa cylindrica (L.) M. Roem. Pharmacog J. 2019;11(3):511-4. 